\title{
ABUNDANCE AND FRUGIVORY OF THE TOCO TOUCAN (Ramphastos toco) IN A GALLERY FOREST IN BRAZIL'S SOUTHERN PANTANAL
}

\author{
RAGUSA-NETTO, J. \\ Departamento de Ciências Naturais, Campus Três Lagoas - UFMS, \\ C. P. 210, CEP 79600-000, Três Lagoas, MS, Brazil \\ Correspondence to: José Ragusa-Netto, Departamento de Ciências Naturais, Campus Três Lagoas - UFMS, \\ C. P. 210, CEP 79600-000, Três Lagoas, MS, Brazil, e-mail: forpus@ ceul.ufms.br \\ Received May 24, 2004 - Accepted October 1, 2004 - Distributed February 28, 2006
}

(With 3 figures)

\begin{abstract}
Unlike other toucan species, the Toco toucan (Ramphastos toco) - the largest Ramphastidae - usually inhabits dry semi-open areas. This conspicuous canopy frugivore uses a large home range that includes a variety of vegetation types, among which gallery forests are widely cited as important to this species. However, the factors relating to the occurrence of Toco toucans in such habitats are unclear. I studied the abundance of Toco toucans as well as the availability of fleshy fruit in a gallery forest in the southern Pantanal (sub-region of Miranda, Brazil), in order to assess the relationship between these parameters. Also, I examined toucan foraging activity to analyze its relationship with both toucan abundance and fruit availability. The presence of the Toco toucan was more common in the gallery forest from the middle to the end of the dry season and during the middle of the wet season. Toucans foraged for fleshy fruits, mainly Genipa americana, Ficus luschnatiana, and Cecropia pachystachya fruits, feeding mostly on G. americana (by far the favorite food resource) and $F$. luschnatiana fruits during the dry season, while C. pachystachya fruits were important in the wet season. Toco toucans foraged particularly heavily ( $>80 \%$ of foraging activity) on G. americana fruits during the latter part of the dry season, when fleshy fruit availability declined sharply. Toco toucan abundance in the gallery forest was associated with the availability of the most commonly consumed fleshy fruits, and also with its foraging activity. This finding suggests that the Toco toucan moved to the gallery forest periodically in response to the availability of abundant food resources, especially the G. americana fruits widely available and exploited during the severely dry season. Therefore, these fruits potentially contribute to Toco toucan persistence in the South Pantanal during the harshest period of the year.
\end{abstract}

Keywords: Ramphastidae, Ramphastos toco, phenology, gallery forest, frugivory, migration.

\section{RESUMO}

\section{Abundância e exploração de frutos por tucano toco (Ramphastos toco) em uma mata ciliar no Pantanal Sul}

Dentre as espécies de tucanos, a maior delas, tucano toco (Ramphastos toco), é singular, uma vez que é muito comum em ambientes semi-abertos e/ou com manchas de florestas. As matas ciliares são citadas como ambientes em que essa espécie é comum. No entanto, os fatores relacionados com a ocorrência de $R$. toco, nesse tipo de vegetação, são desconhecidos. Estudei a abundância do tucano toco na mata ciliar do rio Miranda (Pantanal Sul), bem como a oferta de frutos carnosos, com o propósito de avaliar as relações entre esses parâmetros. Também examinei a exploração de frutos para avaliar as relações com a sua disponibilidade, bem como com a ocorrência do tucano toco na mata ciliar. Esse tucano foi mais comum de meados para o final da estação seca e em meados da estação chuvosa. Os frutos de três espécies arbóreas, Genipa americana (de longe o mais utilizado), Ficus luschnatiana e Cecropia pachystachya, 
foram amplamente consumidos. Os frutos das duas primeiras espécies destacaram-se durante a estação seca, enquanto os frutos da terceira foram importantes na estação chuvosa. O uso dos frutos de G. americana foi particularmente intenso, sendo que, ao final da estação seca, mais de $80 \%$ dos registros de alimentação incluíram essa espécie, quando a oferta de frutos carnosos declinou substancialmente. A ocorrência do tucano toco na mata ciliar foi significativamente relacionada com a oferta dos frutos mais utilizados e, também, com a atividade de exploração desses recursos. Esses resultados sugerem que, periodicamente, o $R$. toco movimentava-se para a mata ciliar em resposta à oferta de recursos alimentares abundantes, sobretudo os frutos de G. americana, amplamente disponíveis durante a rigorosa estação seca. Portanto, esse recurso potencialmente contribui para a persistência do $R$. toco no Pantanal Sul durante o período mais severo do ano.

Palavras-chave: Ramphastidae, Ramphastos toco, mata ciliar, frugivoria, fenologia.

\section{INTRODUCTION}

Large frugivorous birds usually have wide home ranges, in which the availability of their food resource is spatially and temporally variable (Levey, 1988, Blake \& Loiselle, 1991; Kinnaird et al., 1996). Such birds search for fruiting patches over large and diverse areas within which the fruiting pattern is asynchronous (Terborgh, 1986). Hence, each habitat type is important at different times (Renton, 2001). As fruits form most of their diet, they largely consume nutritive fruits (Stiles, 1993), which are swallowed and the seeds frequently discarded intact away from the parent tree, substantially enhancing seed dispersal success (Howe \& Smallwood, 1982; Schupp, 1993).

Toucans (Ramphastidae) are prominent canopy frugivores, which typically wander over wide areas within their home range in order to exploit fruiting trees (Terborgh et al., 1990; Graham, 2001; Galetti et al., 2000). Although toucans are also bizarre nest predators and consume other small vertebrates, besides large arthropods, fruits are by far the major component of their diets (Skutch, 1971; Galetti et al., 2000; Guix et al., 2001). As these birds often ingest large amounts of fruits and fly away from the fruiting tree after a visit, the seeds thus removed are likely to be deposited in suitable sites. Hence, toucans have been assumed as important seed dispersers of many Neotropical tree species (e.g., Howe, 1977, 1981, 1993; Howe \& Vande Kerckhove, 1981). In spite of their conspicuousness, however in the canopy and importance in forest regeneration, toucans remain largely unstudied with respect to their feeding ecology and pattern of abundance (however, see Galetti et al., 2000, Graham, 2001; Guix et al., 2001).

The Toco toucan (Ramphastos toco) is the largest toucan species, which is widely distributed in the interior of Brazil, being particularly common in the "Cerrado" (del Hoyo et al., 1997; Sick, 1997). Unlike most toucan species that inhabit continuous forests, the Toco toucan occurs in both semi-open and closed habitats. It is also common in the "Pantanal" wetlands (del Hoyo et al., 1997; Sick, 1997), whose vegetation consists mainly of a mosaic of patches of dense forest interspersed with open and semi-open areas (Pott \& Pott, 1994). Among the vegetation types used by such birds, the gallery forests are apparently important to them (del Hoyo et al., 1997; Sick, 1997). However, the factors relating to their association with watercourses are still unclear. Since toucans rely mostly on fruits, a direct examination of their responses to variations in fruit production in a given habitat may clarify the importance of fruit availability on their local pattern of abundance, as found for other canopy frugivorous birds (Leighton \& Leighton, 1983; Wheelwright, 1983; Kinnaird et al., 1996). Therefore, in this study I assessed the abundance of Toco toucans in a gallery forest in the South Pantanal (Brazil), as well as fleshy fruit production, in order to evaluate the relationship between these parameters. I also examined Toco toucan foraging activity to analyze its relationship with food resource availability and with the species' abundance. 


\section{METHODS}

\section{Study area}

This study was conducted in the South Pantanal flood plain in the gallery forest of the Miranda river (Corumbá, State of Mato Grosso do Sul, $19^{\circ} 35^{\prime} \mathrm{S}, 57^{\circ} 2^{\prime} \mathrm{W}$, altitude $\pm 100 \mathrm{~m}$ ). The vegetation in the area is a mosaic of palm savanna (Copernicia alba), tecoma savanna (Tabebuia aurea), patches of deciduous forest interspersed with open grassy areas and the dense Miranda river gallery forest. This forest is $50-200 \mathrm{~m}$ wide, with an 8-13 m canopy, but emergent trees may reach $17 \mathrm{~m}$. From July to September many tree species shed their leaves, although abundant evergreen species such as Inga vera and Ocotea diospyrifolia contribute to an evident semi-deciduous pattern in this gallery forest. Common tree species are Inga vera, Ocotea diospyrifolia, Tabebuia heptaphylla, Vitex cymosa, Cecropia pachystachya, Genipa americana, Sapium obovatum, and Banara arguta. Annual rainfall is around $1000 \mathrm{~mm}$, most of it occurring from November to March (wet season), when the average temperature is $27^{\circ} \mathrm{C}$, while the average temperature in the dry season (April to October) is $20^{\circ} \mathrm{C}$, with occasional frosts in the cold months (June-July). In this area of the Pantanal, inundation pulses typically occur from January to March (Fig. 1). During floods, the water level in the gallery forest reaches up to $1.5 \mathrm{~m}$.

\section{Flower and fruit abundance}

The phenological study was designed to evaluate the flower and fruit production for frugivorous birds in the gallery forest. Therefore, sampling was not restricted to a particular set of tree species important for one or various frugivorous bird species. Hence, in order to sample flower and fruit production, phenology transects (a total of $5 \mathrm{Km}$ ) were established in four tracts (400-800 $\mathrm{m}$ apart) of the gallery forest. In this habitat, the topography and drainage are not uniform and neither is the effect of floods. Consequently, due to the patchy occurrence and/or distribution of tree species (Oliveira-Filho et al., 1990; OliveiraFilho et al., 1994), I randomly positioned (parallel to the water course) continuous $300 \mathrm{~m}$ transect segments from the river $(5 \mathrm{~m}, 35 \mathrm{~m}, 65 \mathrm{~m}$, and $95 \mathrm{~m}$ ) up to the proximity of the forest edge. Along these trails, a total of 370 trees were numbered with aluminum tags. Trees were selected both if they were located within a $2.0 \mathrm{~m}$ band on either side of the trails and if their diameter at breast height (DBH) was $>30 \mathrm{~cm}$. This criterion was adopted to ensure the inclusion of canopy and emergent trees in this sample, since Toco toucans typically forage in the canopy. Also, a tree was selected only if at least $80 \%$ of the crown was visible from the forest floor. This random sample included 29 tree species, whose importance for the Toco toucan was unknown. Individual crowns were monitored monthly (between day 5 and 10, from April 2000 to

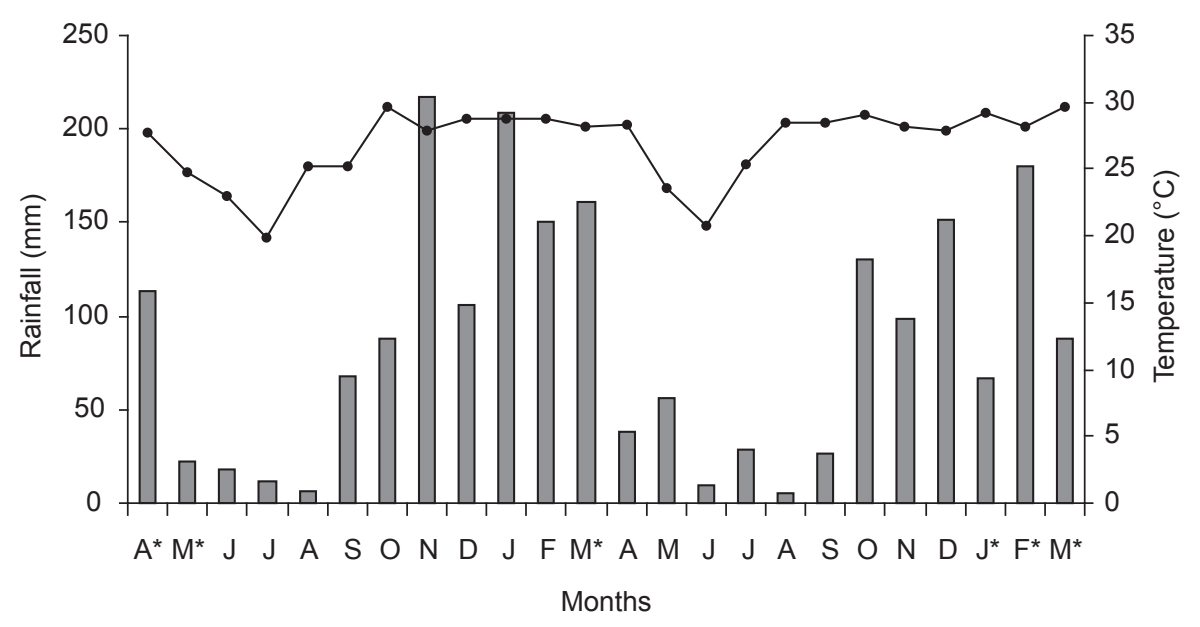

Fig. 1 - Monthly rainfall (columns) and average temperature (line) in the southern Pantanal from Apr 2000 to Mar 2002. The * denotes the flood period. 
March, 2002) for the presence of flowers and fruits with the aid of $8 \times 40$ binoculars. The abundance of flowers, unripe and ripe fruits was noted and ranked on a relative scale ranging from total absence to the full crown capacity of a given phenophase ( 0 to 4 , Fournier, 1974). Thus, the monthly index of resource abundance of a given phenophase resulted from the sum of all abundance scores. Tree species were identified by comparison with samples in the herbarium at the Universidade Federal do Mato Grosso do Sul (Campus Corumbá) and according to Pott \& Pott (1994). An analysis of dispersal syndromes lay outside the scope of this study; hence the fruits were classified only according to the presence of fleshy edible parts rather than dispersal features (zoochory, autochory, and anemochory). Thus, tree species whose dyaspores had a pulp or aril were assigned as species with fleshy fruit, whereas those with a dry mesocarp were classified as species with dry fruits.

\section{Toco toucan abundance}

To sample Toco toucan abundance, point counts were used because this is a suitable technique for estimating canopy bird abundance in closed habitats (Marsden, 1999). Along the routes established for phenological studies, I positioned 18 points ( $300 \mathrm{~m}$ apart from each other) from which Toco toucans were counted. Monthly, Toco toucans were counted during three mornings (six points/morning; between day 5 and 10) without rain or heavy mist. At each point, all the Toco toucans seen or heard during $10 \mathrm{~min}$ were recorded, irrespective of the distance from the census station (variable circular plot, Bibby et al., 1992). All census work was carried out from $6: 30 \mathrm{~h}$ to approximately $8: 30 \mathrm{~h}$ in the dry season and from $6 \mathrm{~h}$ to $8 \mathrm{~h}$ in the wet season. The Toco toucans observed and/or heard flying by over the gallery forest (their wing beat produced a distinctive sound) were not recorded, since the closed canopy made it difficult to follow them until they landed on a specific type of vegetation.

\section{Toco toucan resource use}

To sample the consumption of flowers and fruits by Toco toucans, their feeding activity was observed directly. Every month I walked the aforementioned trails, sampling both Toco toucan and resource abundance ( $30 \mathrm{~h} / \mathrm{month}$ ) from 6 to
$11 \mathrm{~h}$ and from 15 to $18 \mathrm{~h}$, when Toco toucans were usually foraging. Whenever at least one feeding Toco toucan was detected, I recorded: a) tree species; b) food resource (flower or fruit); c) part eaten (petal, pulp, or aril); d) the number of Toco toucans foraging; and e) the time and date. Thus, a feeding record consisted of at least one Toco toucan feeding on a food resource, irrespective of time spent foraging and amount of food ingested. As feeding records were used in correlation analyses, I used only the initial observation to ensure independence among foraging samplings. Moreover, as toucans often forage on large fruit crops, I assumed that they were equally likely to be seen while feeding on such abundant food resources (Hejl et al., 1990).

\section{Analyses}

The number of Toco toucans recorded monthly from the 18 points was taken as a monthly index of Toco toucan abundance. The Spearman rank correlation was used to evaluate the relationship between Toco toucan abundance and resource availability. The monthly indices of both resource and Toco toucan abundance were taken as variables. The relationship between Toco toucan abundance and foraging activity, as well as the relationship between resource availability and foraging activity was also evaluated through non-parametric correlation analyses. The monthly percentage of feeding records was then taken as an index of foraging activity and correlated (Spearman rank correlation) both with resource and Toco toucan abundance.

\section{RESULTS}

\section{Flower and fruit production}

The 29 tree species recorded in the phenology transects belong to 18 families. Most species (66\%) and trees $(80 \%, \mathrm{~N}=370$ trees) produced fleshy fruits, while only 10 species and 76 trees produced dry fruits. Among the most common species were Inga vera (66 trees), Ocotea diospyrifolia (62), Vitex cymosa (43), Tabebuia heptaphylla (36), Cecropia pachystachya (24), and Genipa americana (24). Two major flowering peaks were recorded annually: the first one emerged in the middle of dry the season, mainly due to the flowering of Tabebuia heptaphylla and Ocotea 
diospyrifolia, while a very pronounced flowering peak occurred during the transition from the dry to the wet season (Figs. 1 and 2). This massive flower production came from the flowering of Vitex cymosa, Cecropia pachystachya, Genipa americana, and the highly abundant Inga vera, whose intense flowering in both years lasted two months (Fig. 2). Another, though minor, flower production resulted from the flowering of species (mainly Banara arguta and Sapium obovatum) often exposed to floods for longer periods. Flowering of these species was marked during February, 2001 (later wet season), but less evident during the same period in 2002 (Fig. 2). The fruiting pattern displayed two evident annual peaks: the first and strongly marked one occurring during the middle of the wet season (December-February; for unripe fruits, the peaks occurred a month earlier), and the second peak appearing during the transition from the wet to the dry season (March-May; Fig. 2). The massive fruit production in the middle of the wet season (January, 2001) resulted mainly from the fruiting of Vitex cymosa, Ocotea diospyrifolia, and Cecropia pachystachya. However, in the second wet season, Ocotea diospyrifolia failed to produce fruits, and Cecropia pachystachya bore fruits later. Thus, the large fruit crop of Vitex cymosa comprised most of the fruit production in that period (Fig. 2). The peak of fruit abundance during the transition from the wet to the dry season resulted from the fruiting of Banara arguta, Sapium obovatum, Crataeva tapia, Copernicia alba, and Inga vera. The latter, despite its massive flowering, generally produced a small fruit crop, while Banara arguta and Sapium obovatum bore very large fruit crops, which comprised most of this fruiting peak, whose maturation occurred simultaneously with the annual floods.

\section{Toco toucan food resources use}

Toucans foraged on 11 plant species of 11 families, making a total of 88 feeding records
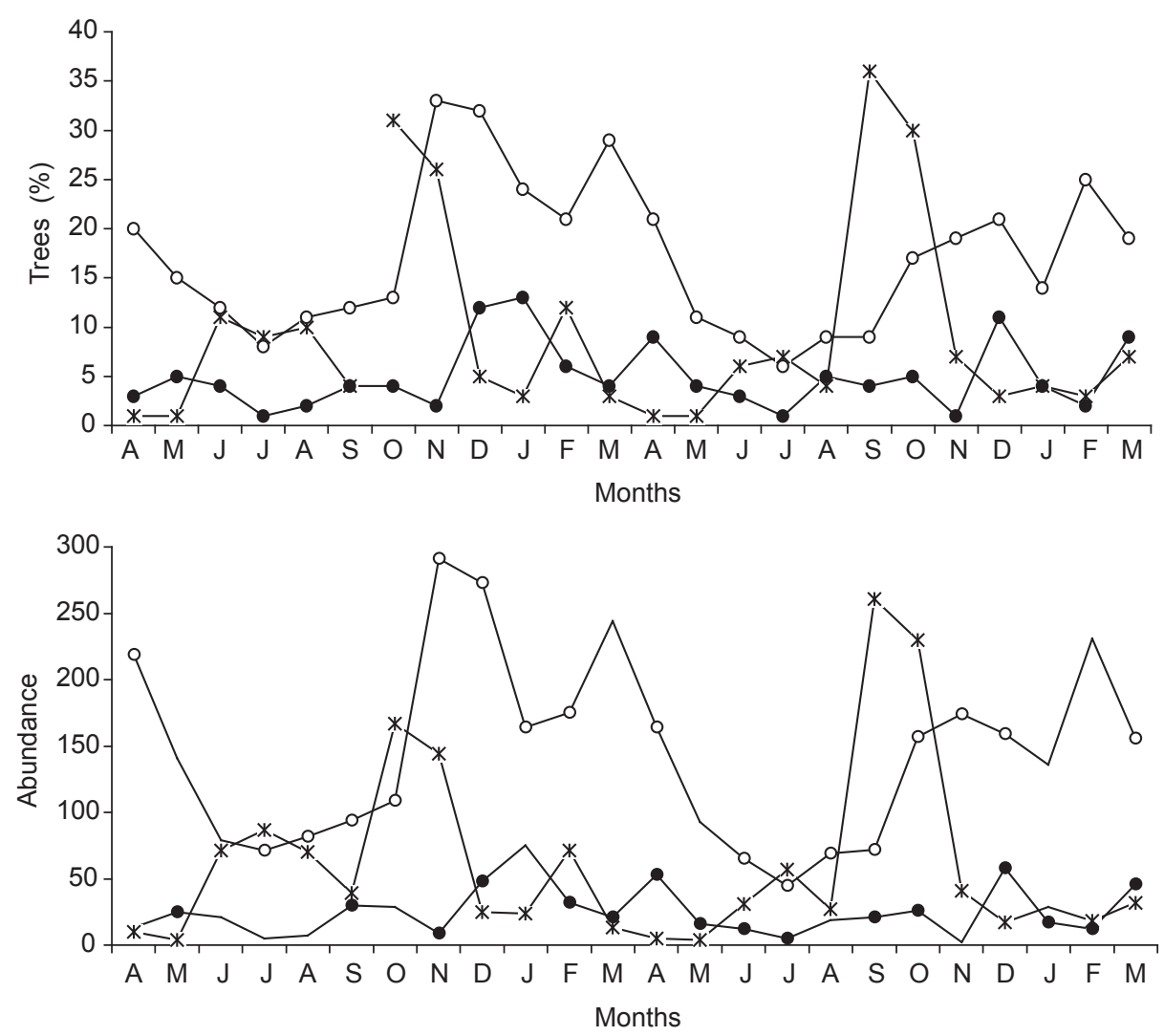

Fig. 2 - Percentage of flowering trees $(*, N=370$ ), trees bearing immature (open circles) and mature (solid circles) fruits, and (below) the abundance of these resources in the Miranda river gallery forest. 
involving 113 individuals. With the exception of only one record of flower consumption, the toucans foraged exclusively for fleshy fruits (Table 1). Also, only once were toucans found to consume fruits from a climber (Paullinia pinnata), while fruits of canopy tree species predominated in the Toco toucan diet. Important food items such as Genipa americana and Cecropia pachystachya fruits (>50\% of feeding records, when grouped, Table 1) were ingested piecemeal, while most other fruits were ingested whole.

Toco toucans foraged in the gallery forest mainly during the dry season, when the foraging activity was higher (65\%, Table 1, Fig. 3). Five tree species were important in this period. From the early to mid-dry season, toucans mostly fed on fruits of the palm Copernicia alba and Cecropia pachystachya, besides Inga vera arils. On the other hand, from the middle to the end of the dry season, toucans heavily consumed Genipa americana and Ficus luschnatiana fruits (Table 1). While G. americana was a common species in the gallery forest, only a few, albeit large trees of $F$. luschnatiana occurred in the sampled area. Although both species bore large fruit crops, they exhibited a contrasting fruiting pattern. The few fig trees asynchronously fruited during a short period, while G. americana fruited synchronously, although its fruits matured asynchronously within a given crown during a three-four month period. Hence, every year $G$. americana fruits were available and consumed by the Toco toucan during most of the dry season (Table 1).

During the wet season, toucans concentrated almost exclusively on three tree species (Cecropia pachystachya, Ocotea diospyrifolia, and Vitex cymosa, Table 1). However, in this period toucans mostly foraged for C. pachystachya fruits, which bore a large fruit crop that matured from the middle to the end of the wet season. Hence, for approximately three months, this was the most important food resource for toucans in the gallery forest.

\section{Toco toucan abundance}

The abundance of Toco toucans varied throughout the year. From zero to four toucans were recorded monthly (Fig. 3), with the highest peak of abundance occurring in December 2000, while in 10 out of 24 months no toucan was detected during the census work. Except for January to May 2001, when toucans were absent, their abundance in the gallery forest was characterized by periods of occurrence (one to three months), alternating with their absence. Furthermore, when present, one to four toucans were recorded monthly, suggesting a sparse occurrence (Fig. 3). Even then, in some periods, the presence of toucans in the gallery forest was consistent with the availability of fruits they most fed on. For example, from the middle to the end of the dry season the fruits of the most consumed species, Genipa americana,

TABLE 1

Plant species and items eaten by Ramphastos toco $(\mathrm{N}=\mathbf{8 8}$ feeding records), and toucans recorded foraging in the Miranda river gallery forest (Pantanal, Brazil).

\begin{tabular}{|l|c|l|r|r|}
\hline \multicolumn{1}{|c|}{ Family/Species } & Item* & \multicolumn{1}{|c|}{ Month } & $\begin{array}{c}\text { Feeding records } \\
(\%)\end{array}$ & Toucans \\
\hline Arecaceae/Copernicia Alba & $\mathrm{p}$ & Apr, May & 7.0 & 8 \\
\hline Bignoniaceae/Tabebuia heptaphylla & $\mathrm{f}$ & Aug & 1.0 & 1 \\
\hline Cecropiaceae/Cecropia pachystachya & $\mathrm{p}$ & Jan, Feb, March, May, Jun, Nov, Dec & 25.0 & 35 \\
\hline Erytroxilaceae/Erytroxilum anguifugum & $\mathrm{p}$ & Nov & 3.0 & 3 \\
\hline Flacourtiaceae/Banara arguta & $\mathrm{p}$ & Apr & 1.0 & 1 \\
\hline Lauraceae/Ocotea diospyrifolia & $\mathrm{p}$ & Jan, Feb & 6.5 & 6 \\
\hline Leguminosae/Inga vera & $\mathrm{a}$ & March, Apr & 8.5 & 8 \\
\hline Moraceae/Ficus luschnathiana & $\mathrm{p}$ & Aug, Sept, Oct & 13.0 & 16 \\
\hline Rubiaceae/Genipa Americana & $\mathrm{p}$ & Jul, Aug, Sept, Oct & 30.0 & 30 \\
\hline Sapindaceae/Paullinia piannata & $\mathrm{a}$ & May & 1.0 & 1 \\
\hline Verbenaceae/Vitex cymosa & $\mathrm{p}$ & Dec & 4.0 & 8 \\
\hline
\end{tabular}

*Item consumed: $\mathrm{a}=$ aril, $\mathrm{f}=$ flower, $\mathrm{p}=$ pulp. 

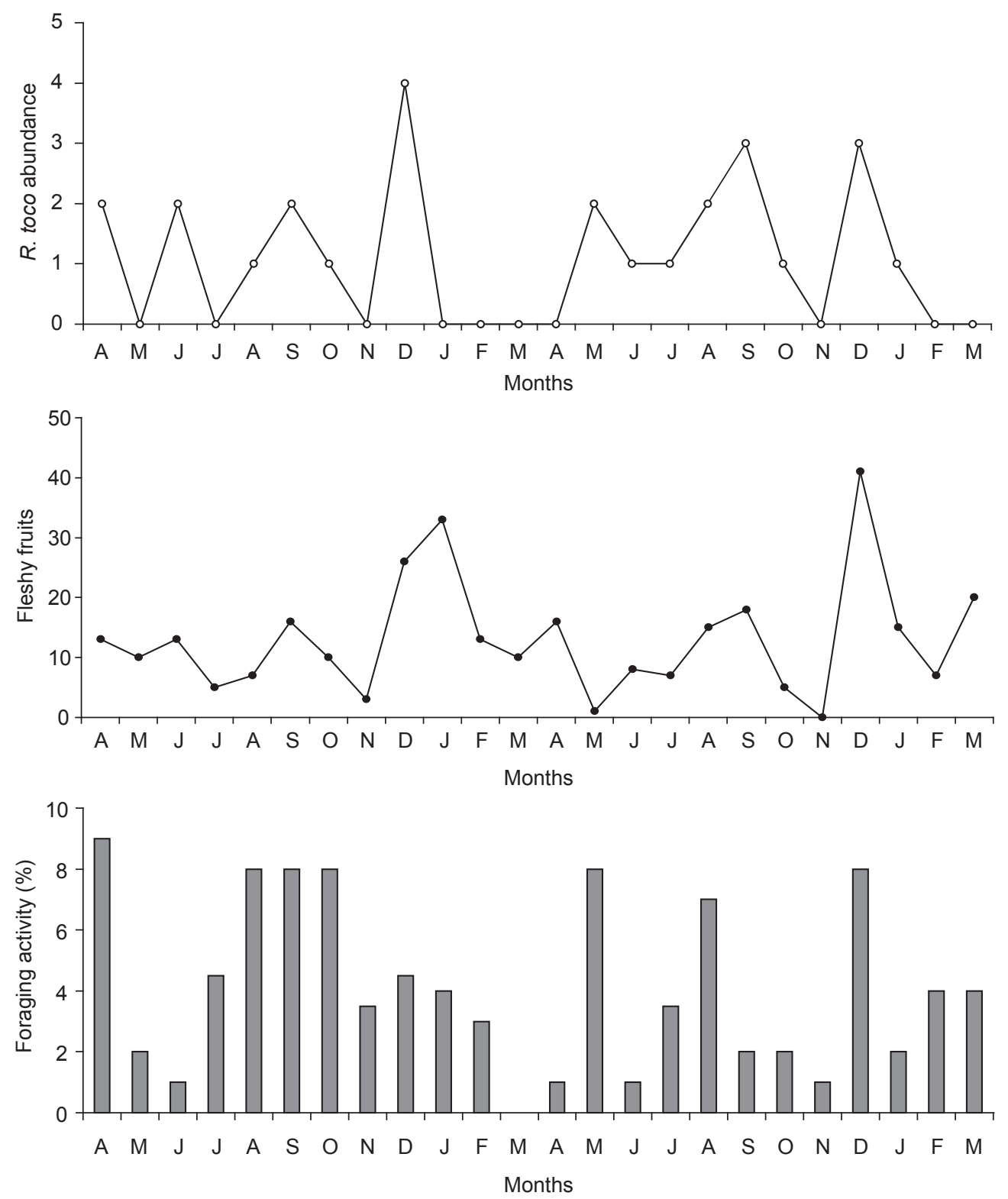

Fig. 3 - From top to bottom: monthly Toco toucan abundance, fleshy fruits abundance ( $>5 \%$ of feeding records), and percentage of feeding records $(\mathrm{N}=88)$ in the Miranda river gallery forest.

matured progressively and toucans were recorded simultaneously in the gallery forest. During the wet season (mainly December) toucans were also often present in the gallery forest when important resources such as Cecropia pachystachya, Ocotea diospyrifolia, and Vitex cymosa fruits were available (Table 1, Fig. 3). Such coincidences between toucan occurrence and the availability of the most consumed fruits ( $>5 \%$ of feeding records) were correlated (Spearman rank correlation, $r_{s}=0.42$, $\mathrm{P}<0.05$, Fig. 3). Given that toucan presence was associated with the availability of important food resources, the relationship between toucan occurrence in the gallery forest and its foraging activity also showed a significant correlation $\left(r_{s}=0.41, P<0.05\right.$, Fig. 3). 


\section{DISCUSSION}

\section{Resource abundance}

The Miranda river gallery forest is part of a vegetation mosaic which includes deciduous and semi-deciduous habitats. While the patches of deciduous forest near the gallery forest have a similar number of tree species that produce fleshy fruits and dry fruits (Araújo, 2001), my phenology sample within the gallery forest itself suggested a preponderance of species with fleshy fruits. Most importantly, trees that produce fleshy fruits predominated in the phenology sample. Therefore, this gallery forest appears to be an important source of fleshy fruits in the highly seasonal Pantanal, mainly in the wet season and transition to the dry, during flood pulses.

The two conspicuous annual fruiting peaks presumably resulted from the influence of distinct environmental factors on two groups of tree species. The pronounced fruiting peak in the middle of the wet season followed a typical fruiting pattern conforming to rainfall seasonality, as found in other Neotropical semideciduous forests (Frankie, et al., 1974; Bullock \& Solis-Magallanes, 1990; Peres, 1994). During the rainy season, fleshy fruits predominated in the Miranda river gallery forest. However, a marked fleshy fruit production during the wet season is typical for tropical dry forests (Frankie, et al., 1974; Griz \& Machado, 2001). Apparently, such a pattern is also usual for Neotropical gallery forests within dry areas (Funch et al. 2002). Fruiting during rains favors seed germination as well as rapid seedling growth, serving to reduce seedling mortality resulting from unfavorable environmental conditions to which markedly seasonal forests are exposed for long periods each year (van Schaik, et al., 1993). In fact, few species (e.g., Genipa americana) bore solely fleshy fruits during the dry season in the Miranda river gallery forest.

The other fruiting peak, more conspicuously involving species with fleshy fruits (Fig. 3), originated from trees (mainly Banara arguta and Sapium obovatum) often exposed to floods for longer periods. Such species bore ripe fruits simultaneously to inundations, dropping a large number of diaspores into the water (pers. obs.). This fruiting pattern resembled that of the Amazonian flood plain, in which a community-wide fruiting peak coincides with forest inundation and most fruits are adapted to water or fish dispersal (Kubitzki \& Ziburski, 1994).

The availability of fleshy fruit in the Miranda river gallery forest resulted mainly from the enhanced fruit production of few tree species during the dry and rainy seasons. Although very few species bore fleshy fruits during the dry season, species such as $G$. americana were very important since their fruits represented a plentiful food source during a substantial part of this rigorous period in the southern Pantanal.

\section{Toco toucan food resources use and abundance}

Although toucans are prominent canopy frugivores and important seed dispersers (Howe 1981; 1993), few studies have focused on their year-round diet (see Skutch, 1971; Galetti, et al, 2000; Guix, et al., 2001). Most fruits consumed by Toco toucans in the gallery forest were also found in the diet of toucans studied elsewhere. Particularly palm, Inga, Cecropia, and Lauraceae fruits, besides figs, are among the major resources for toucan species, for which detailed foraging data are available (Skutch, 1971; Galetti et al., 2000; Guix, et al., 2001). However, unlike other toucan species, Toco toucans extensively used Genipa americana fruits during the harshest period of the year.

The resources most used by Toco toucans in the gallery forest are common in light gaps and secondary forests. Fruit production in these vegetation types tends to be higher than in mature forests and year-round fruit availability appears to suffice for a permanent, albeit variable, attraction of frugivorous birds (Levey, 1988; Blake \& Loiselle, 1991). Toco toucans extensively consumed three species (Genipa americana, Cecropia pachystachya and Ficus luschnatiana), which bore a very large fruit crop but displayed different phenological patterns. Ficus luschnatiana, as other fig species, fruited asynchronously (Milton, et al., 1982; Ragusa-Netto, 2002), while C. pachystachya bore fruits two or three times per year, and G. americana synchronously produced a large fruit crop that gradually matured from the middle to the end of the dry season. These resources were available simultaneously only during the dry season, when Toco toucans forage mostly in the gallery forest. Such fruits, poor in lipids and proteins (Wheelwright et al., 1984; Stiles, 1993), were also consumed by toucans from the Atlantic 
forest (Ramphastos dicolorus and R. vitellinus), although they regularly foraged for lipid-rich diaspores (Galetti et al., 2000). Such fruits, often dispersed by toucans (Howe, 1981; 1993), were very scarce in the gallery forest. Therefore, despite their low nutritional quality, the most abundant fruits were important for Toco toucans. The extensive use of lipid- and protein-poor fruits is common among large canopy frugivorous birds in Southern Asian rain forests. Although, in principle, inadequate for vertebrates such as birds, the energy content and presence of some important nutrients in these fruits are useful for maintenance and even chick development (Kinnaird et al., 1996).

Among the fruits most extensively consumed by Toco toucans, G. americana fruits were particularly important since, during the dry season, they comprised almost 50\% of feeding records. Most importantly, in the latter part of this period more than $80 \%$ of the foraging activity included this resource, when the availability of fleshy fruit declined sharply (Fig. 2). The total fruit consumption was not assessed at every toucan visit to a fruiting G. americana. However, on many occasions I observed toucans probing several fruits to evaluate their ripeness, and once they found a suitable fruit, a substantial proportion, if not the whole fruit, was ingested piecemeal. Hence, these observations also indicate that $G$. americana fruits are an intensively used resource, potentially contributing to the persistence of Toco toucans during the severe dry season in the southern Pantanal. In addition, several bird species foraged avidly on these fruits (from the small Ramphocelus carbo to the large Ortalis canicollis, pers. obs.), which are also important for fishes and primates in the Pantanal (Pott \& Pott, 1994). Therefore, a large and diverse assemblage of vertebrates presumably benefits from using the large annual fruit crops of G. americana.

Unlike most other toucan species, the Toco toucan is more common in semi-open areas (del Hoyo et al., 1997; Sick 1997). Therefore, mesoscale displacements from one habitat type to another while foraging are usual for such birds (Graham, 2001). During this study, I observed Toco toucans on several occasions flying over large open areas, either arriving at or departing from the gallery forest. These observations, together with the uneven occurrence of these birds in the gallery forest, suggest that they used this habitat as part of their home range. As
Toco toucans were only recorded foraging ( $>2000$ $\mathrm{h}$ observations) rather than breeding or roosting, food resources were presumably the major cause for their movements to the gallery forest. In continuous wet forest, the home range of Ramphastos spp. is around 40-50 ha (Terborgh et al., 1990). Since the Toco toucan is the largest species, its home range is potentially even larger, because home range size of bird species is positively related to bird body size (Schoener, 1968). Thus, the use of a large and diverse home range might explain the pattern of Toco toucan occurrence in the gallery forest, which resembles the pattern of local abundance of frugivorous birds that move around within a local habitat mosaic according to fruit availability in different vegetation types (Leighton \& Leighton, 1983; Wheelwright, 1983; Powell \& Björk, 1994). As fleshy fruit availability in the gallery forest was markedly seasonal, Toco toucans presumably used neighboring areas such as patches of deciduous forest (rich in fig trees; pers. obs.) during periods of minimum food availability. Hence, further long term and multi-habitat studies in the Pantanal, focusing upon the Toco toucan's pattern of abundance and feeding ecology, will increase our knowledge about the Toco toucan's use of a vegetation mosaic that encompasses asynchronous patches of fruits. Such ecological data cannot but improve our prospects for conservation of the Toco toucan, a large canopy forager undoubtedly important for forest regeneration in the southern Pantanal and elsewhere.

Acknowledgments - I am indebted to Alan Fecchio, Gesner Batista Ramos, Jacqueline Vasquez, André Silveira and Cláudia Bitencourt for their assistance in the field. Edilson, Rosemar, Rosana and Josefa provided logistical support at BEP/UFMS. Thanks are also due to Rosilene Rodrigues-Silva for her help in the identification of some plant species. Financial support was provided by FUNDECT and PROPP/UFMS (Brazil).

\section{REFERENCES}

ARAUJO, A. C., 2001, Flora, fenologia de floração e síndromes de polinização em capões do Pantanal sul mato grossense. $\mathrm{PhD}$ Thesis, Unicamp.

BLAKE, J. G. \& LOISELLE, B. A., 1991, Variation in resource abundance affects capture rates of birds in three lowland habitats in Costa Rica. Auk, 108: 114-130.

BIBBY, C. J., BURGESS, N. D. \& HILL, D. A., 1992, Bird census techniques. London, Academic Press.

BULlOCK, S. H. \& SOLIS-MAGALLANES, J. A., 1990, Phenology of canopy trees of a tropical deciduous forest in Mexico. Biotropica, 22: 22-35. 
DEL HOYO, J., ELLIOT, A. \& SARDATAL, J., 1997, Handbook of the birds of the world, Vol 7. Sangrouse to Cuckoos. Lynx, Barcelona.

FOURNIER, L. A., 1974, Un método cuantitativo para la medición de características fenológicas en arboles. Turrialba, 24: 422-423.

FRANKIE, G. W., BAKER, H. G. \& OPLER, P. A., 1974, Comparative phenological studies of trees in tropical wet and dry forests in the lowlands of Costa Rica. J. Ecol., 62: 881-919.

FUNCH, L. S., FUNCH, R. \& BARROSO, G. M., 2002, Phenology of gallery and montane forest in the Chapada Diamantina, Bahia, Brazil. Biotropica, 34: 40-50.

GALETTI, M., LAPS, R. \& PIZO, M. A., 2000, Frugivory by Toucans (Ramphastidae) at Two Altitudes in the Atlantic Forest of Brazil. Biotropica, 32: 842-850.

GRAHAM, C. H., 2001, Factors influencing movement patterns of kell-billed toucans in fragmented tropical landscape in southern Mexico. Conserv. Biol., 15: 1789-1798.

GRIZ, L. M. S. \& MACHADO, I. C. S., 2001, Fruiting phenology and seed dispersal syndromes in caatinga, a tropical dry forest in the northeast of Brazil. J. Trop. Ecol., 17: 303-321.

GUIX, J. C., RUIZ, X. \& JOVER, L., 2001, Resource partitioning and interspecific competition among coexisting species of guans and toucans in SE Brazil. Neth. J. Zool., 51: 285-297

HEJL, S. J., VERNER, J. \& BELL, W., 1990, Sequential versus initial observations in studies of avian foraging. Stud. Av. Biol., 13: 166-173.

HOWE, H. F., 1977, Bird activity and seed dispersal of a tropical wet forest tree. Ecology, 58: 539-550.

HOWE, H. F., 1981, Dispersal of a Neotropical nutmeg (Virola sebifera) by birds. Auk, 98: 88-98.

HOWE, H. F., 1993, Aspects of variation in a Neotropical seed dispersal system. Vegetatio, 107/108: 149-162.

HOWE, F. H. \& SMALLWOOD, J., 1982, Ecology of seed dispersal. Ann. Rev. Ecol. Syst., 13: 201-228.

HOWE, H. F. \& VANDE KERCKHOVE, A. G., 1981, Removal of wild nutmeg (Virola surinomensis) Crops by birds. Ecology, 62: 1093-1106.

KINNAIRD, M. F., O'BRIEN, T. G. \& SURYADI, S., 1996, Population fluctuation in Sulawesi Red-Knobbed Hornibills: tracking figs in space and time. Auk, 113: 431-440.

KUBITZKI, K. \& ZIBURSKI, A., 1994, Seed dispersal in flood plain forest of Amazonia. Biotropica, 26: 30-43.

LEIGHTON, M. \& LEIGHTON, D., 1983, Vertebrate responses to fruiting seasonality within a bornean rain forest. In: S. L. Sutton, T. C. Whitmore \& A. C. Chadwick (eds.). Tropical Rain Forest: Ecology and Manageament. Blackwell Scientific Publications, Oxford, England.

LEVEY, D. J., 1988, Spatial and temporal variation in Costa Rican fruit and fruit-eating bird abundance. Ecol. Monog., 58: 251-269.
MARSDEN, S. J., 1999, Estimation of parrot and hornbill densities using a point count distance sampling method. Ibis, 141: 377-390.

MILTON, K., WINDSOR, D. M., MORRISON, D. W. \& ESTRIBI, M. A., 1982, Fruiting phenologies of two tropical Ficus species. Ecology, 63: 752-762.

OLIVEIRA-FILHO, A. T., RATTER, J. A., SHEPERED, G. J., 1990, Floristic composition and community structure of a Brazilian gallery forest. Flora, 184: 103-117.

OLIVEIRA-FILHO, A. T., VILELA, E. A., CARVALHO, D. A., GAVILANES, M. L., 1994, Effects of soils and topography on the distribution of tree species in a tropical riverine forest in south-eastern Brazil. J. Trop. Ecol., 10: 483-508.

PERES, C. A., 1994, Primate responses to phenological changes in an Amazonian terra firme forest. Biotropica, 26: 98-112.

POTT, A. \& POTT, V. J., 1994, Plantas do Pantanal. Brasília, Embrapa, 320p.

POWELL, V. N. G. \& BJÖRK, R. D., 1994, Implications of altitudinal migration for conservation strategies to protect tropical biodiversity: a case study of the quetzal Pharomachrus mocinnoi at Monte Verde, Costa Rica. Bird. Conserv. Inter., 4: 243-255.

RAGUSA-NETTO, J., 2002, Fruiting phenology and consumption by birds in Ficus calyptroceras (Miq.) Miq. (Moraceae). Braz. J. Biol., 62: 339-346.

RENTON, K., 2001, Lilac-crowned parrot diet and food resource availability: resource tracking by a parrot seed predator. Condor, 103: 62-69.

SCHOENER, T. W., 1968, Sizing feeding territories among birds. Ecology, 49: 123-141.

SCHUPP, E. W., 1993, Quantity quality, and the effectiveness of seed dispersal by animals. Vegetatio, 107/108: 15-29.

SICK, H., 1997, Ornitologia Brasileira. Nova Fronteira, Rio de Janeiro, 912p.

SKUTCH, A. F., 1971, Life history of the Keel-billed Toucan. Auk, 88: 381-396.

Stiles, E. W., 1993, Influence of pulp lipids on fruit preferences by birds. Vegetatio 107/108: 227-236.

TERBORGH, J., 1986, Keystone plant resources in the tropical forest. In: M. Soule (ed), Conservation Biology. Sinauer, Sunderland, Massachusetts.

TERBORGH, J., ROBINSON, S., PARKER III, T., MUNN, C. \& PIERPONT, N., 1990, Structure and organization of an Amazonian forest bird community. Ecol. Monogr., 60: $213-238$

VAN SCHAIK, C. P., TERBORGH, J. W. \& WRIGHT, S. J., 1993, The phenology of tropical forests, adaptive significance, and consequences for primary consumers. Ann. Rev. Ecol. Syst., 24: 353-377.

WHEELWRIGHT, N. T., 1983, Fruits and the ecology of resplendent quetzals. Auk, 100: 286-301.

WHEELWRIGHT, N. T., HABER, W. A., MURRAY, K. G. \& GUINDON, C., 1984, Tropical fruit eating birds and their food Plants: a survey of a Costa Rican lower montane forest. Biotropica, 16: 173-192. 